\title{
GAMMA SCANNING TECHNIQUE FOR INVESTIGATING DE- ETHANIZER COLUMN: ON FIELD EXPERIMENTAL AT NGL PLANT
}

\author{
Bayu Azmi ${ }^{1 *}$ and Wibisono ${ }^{2}$ \\ ${ }^{1,2}$ Center for Isotopes and Radiation Application, BATAN, Jakarta, Indonesia \\ *Corresponding author: bayuazmi@batan.go.id
}

\begin{abstract}
GAMMA SCANNING TECHNIQUE FOR INVESTIGATING DE-ETHANIZER COLUMN: ON FIELD EXPERIMENTAL AT NGL PLANT. The De-ethanizer column is part of fractionators series at natural gas liquid (NGL) plant. During the production process, there are several common problems that happen such as displaced or damaged trays, dry or flooding trays, unequal liquid level on trays, weeping or dumping trays, foaming on trays, etc. Therefore, investigation of the column's internal condition without interrupting the production process is needed to maintain the production level. Gamma scanning technique has been chosen to investigate the 01-C-3401 de-ethanizer column. The column has two segments, the lower (ID: $1900 \mathrm{~mm}$ ) and the upper (ID: $3200 \mathrm{~mm}$ ) segments. Total column height (TL to TL) is $36710 \mathrm{~mm}$. The scanning was conducted by positioning the collimated gamma source (Co-60, $2.59 \mathrm{GBq})$ and detector $(\mathrm{NaI}(\mathrm{Tl}))$ flanking the column. The collimators move up in parallel by $50 \mathrm{~mm}$ and the detector counted radiation that penetrated column for 3 seconds every scanning step. The scanning process was performed automatically using a winch with AC motor, microcontroller module, computer with LabVIEW as a graphical user interface (GUI). The results show mechanical structures of tray \#1 - \#38 were in good condition. There were no collapsed or flooded trays in the column. The demister was in its position. Chimneys above tray \#38 and tray \#8 were observed exist. The liquid level during the scanning process was in normal liquid level (NLL) approaching to high liquid level (HLL). Gamma scanning technique has been successful to provide the internal structure condition information of the column.
\end{abstract}

Keywords: field experiment; gamma scanning; industry; NGL; process column

\section{ABSTRAK}

TEKNIK GAMMA SCANNING UNTUK INVESTIGASI KOLOM DE-ETHANIZER: EKSPERIMEN LAPANGAN DI PABRIK LNG. Kolom de-ethanizer merupakan bagian dari serangkaian fraksinator pada pabrik gas alam cair. Selama proses produksi, terdapat beberapa masalah yang umum terjadi seperti tray berpindah atau hancur, tray kering atau banjir, level cairan yang tidak merata pada tray, cairan yang menetes atau terbuang pada tray, tray yang berbusa, dan lain sebagainya. Oleh karena itu, diperlukan pemeriksaan kondisi internal kolom tanpa harus mengganggu proses produksi untuk menjaga level produksi. Teknik gamma scanning dipilih untuk memeriksa kolom de-ethanizer 01-C-3401. Kolom tersebut memiliki dua segmen, yaitu segmen bawah (ID: $1900 \mathrm{~mm}$ ) dan atas (ID: $3200 \mathrm{~mm}$ ). Total tinggi (TL ke TL) adalah $36710 \mathrm{~mm}$. Pemindaian dilakukan dengan cara memposisikan sumber gamma (Co-60, 2,59 $\mathrm{GBq}$ ) dan detektor (NaI(Tl)) yang terkolimasi mengapit kolom. Kolimator sumber bergerak naik secara paralel setinggi $50 \mathrm{~mm}$ dan detektor mencacah radiasi yang menembus kolom selama 3 detik setiap stepnya. Proses pemindaian dilakukan secara otomatis dengan peralatan yang terdiri dari winch dengan motor AC, modul miktokontroler sebagai pengendali, dan komputer dengan software LabVIEW sebagai graphical user interface (GUI). Hasil pemindaian menunjukkan struktur mekanik pada tray \#1 - \#38 dalam kondisi yang baik. Demister berada pada posisinya. Chimney di atas tray \#38 dan tray \#8 terdeteksi sesuai dengan gambar mekaniknya. Level liquid selama proses pemindaian berada pada normal liquid level (NLL) mendekati high liquid level (HLL). Teknik gamma scanning telah berhasil memberikan informasi kondisi struktur internal pada kolom.

Kata kunci: eksperimen lapangan; gamma scanning, industri; NGL; kolom proses 


\section{INTRODUCTION}

Natural gas is often liquefied for efficient transportation, and liquefaction is a high energy consumption process [1]. A natural gas liquid (NGL) plant consists of a series of fractionators such as de-methanizer, de-ethanizer, de-propanizer, de-butanizer, and butane splitter. De-ethanizer column aims to remove ethane from product fed by demethanizer. There are several problems that usualy occur during de-ethanization processes such as the low recovery of propane and propylene, refrigeration problems, $\mathrm{CO}_{2}$ removal problems, and carryover problems [2]. The problems can cause by inappropriate process parameters or the malfunction of the process column.

Gamma scanning is a nuclear inspection technique widely used to troubleshoot industrial equipment in refineries and petrochemical plants such as distillation columns, pipes, and reactors [3]. The working principle of the technique is based on gammaray transmission technique, column profile inversely to the density of columns passed by gamma rays. By comparing the mechanical image of the column with the gamma absorption profile, a number of common malfunctions in the column can be immediately identified as shown in Table 1 [4].

In comparison to other non-destructive control techniques used in practice, gamma scanning provides real-time, the clearest vision of the production conditions inside a reservoir of the process [5]. Shahabinejad et al. have been conducted several lab-scale gamma column scanning experiments [6],[7]. They were studied about the application of gamma scanning in the trayed column including optimization of the design of the collimators.

Wibisono et.al. have been performed on field experiments using gamma scanning technique [8]-[10]. They have investigated columns and pipes in petrochemical plants. One of the experiments was complemented with the gamma tomography technique [10]. The gamma tomography technique was used as the complementary technique of the gamma scanning. It was aimed to study the pall rings distribution in the column.

Gamma scanning technique was used to examine the 01-C-3401 de-ethanizer column of
NGL company in North Sumatera, Indonesia. The unit is a trayed column with the inside diameter of $1900 \mathrm{~mm}$ at the lower segment, $3200 \mathrm{~mm}$ at the upper segment, and the total height of $36710 \mathrm{~mm}$ (TL to TL) with lower segment height is $27210 \mathrm{~mm}$ and upper segment height is $9500 \mathrm{~mm}$. The number of the trays is 38 with 30 trays in the lower segment and 8 trays in the upper segment.

Table 1. Common malfunctions in columns [4].

\begin{tabular}{|c|c|}
\hline $\begin{array}{l}\text { Column } \\
\text { problems }\end{array}$ & Malfunction descriptions \\
\hline Mechanical & $\begin{array}{l}\text { - Displaced or damaged trays, demister } \\
\text { pads, and packing; } \\
\text { - Corrosion resulting in partial tray } \\
\text { damage; } \\
\text { - Missing, collapsed or buckled trays or } \\
\text { man-ways; } \\
\text { - Out-of-place liquid or vapor distributors; } \\
\text { - Level control problems on chimney trays } \\
\text { or base liquid level. }\end{array}$ \\
\hline Flowrate & $\begin{array}{l}\text { - Entrainment-slight, moderate, severe, } \\
\text { jet flooding; } \\
\text { - Weeping or dumping trays; } \\
\text { - Dry or flooded trays due to loading } \\
\text { conditions; } \\
\text { - Unequal liquid levels on trays and in } \\
\text { parting boxes, troughs, and collectors. }\end{array}$ \\
\hline Process & $\begin{array}{l}\text { - Foaming on trays or in reboilers, } \\
\text { condensers, and accumulators; } \\
\text { - Bad distribution of vapor and liquid in } \\
\text { packing; } \\
\text { - Liquid hold-up due to plugging and } \\
\text { fouling; } \\
\text { - Superheated or subcooled feed or } \\
\text { reflux. }\end{array}$ \\
\hline
\end{tabular}

\section{METHODS}

The scanning has been conducted using $2.59 \mathrm{GBq}$ of $\mathrm{Co}-60$ as the transmitter and $\mathrm{NaI}(\mathrm{Tl})$ scintillation detector as the receiver. Scintillation detectors, such as $\mathrm{NaI}(\mathrm{Tl}), \mathrm{BGO}$, LYSO, LSO, and GSO are widely used in gamma scanning and tomography applications [11]-[13]. The gamma source and detector were collimated using lead. There are several types of collimators can be used for both the source and detector, but the panoramic and pinhole collimators for the source and pinhole collimator for the detector are the most widely used ones [14]. For the effectiveness of applications in the field, panoramic collimators with a window height of $20 \mathrm{~mm}$ were used.

The scans were separated into upper and lower segment scans. There are two scans orientation for each segment as shown in Figure 1. The scan orientation lines have to avoid the downcomer. Scan orientation is 
ideally carried out symmetrically between one and another, but there are so many obstacles at the column wall such as nozzle, manhole, platform, gauges, etc.

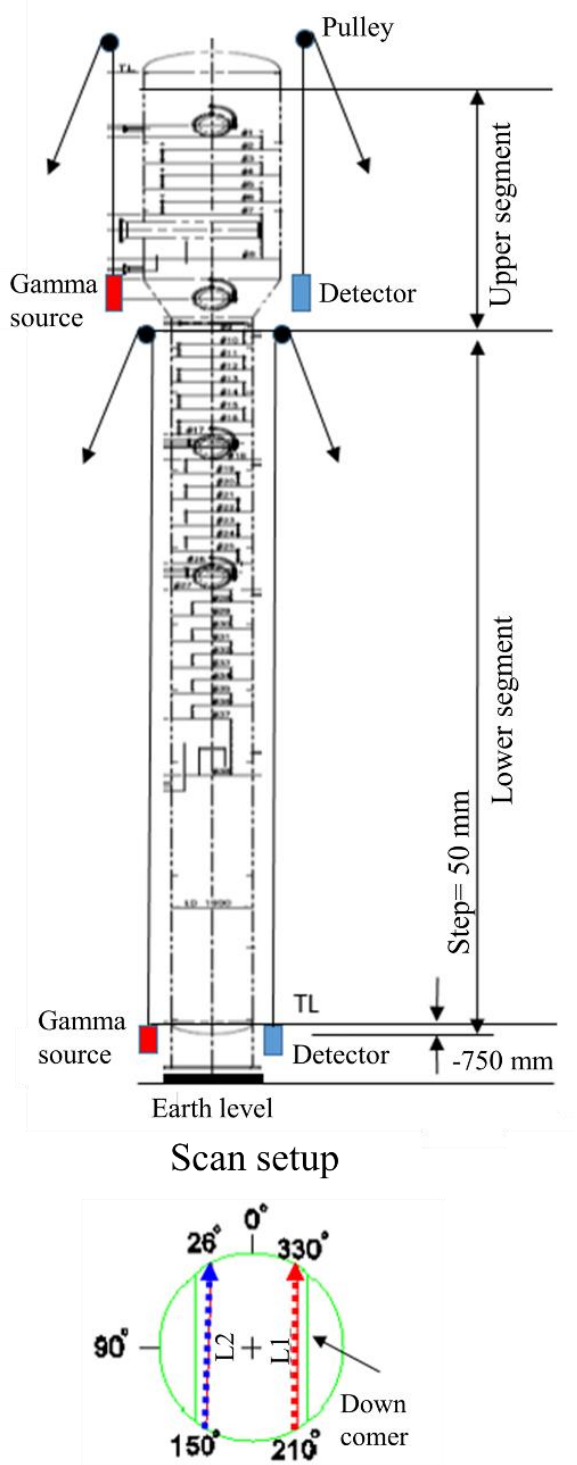

Lower segment scan orientation

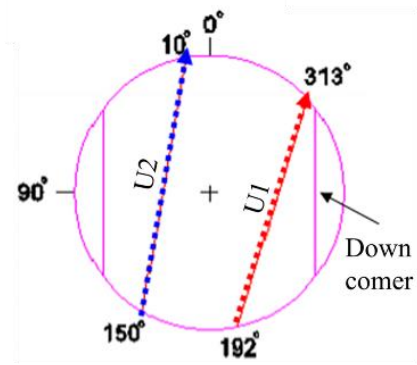

Upper segment scan orientation

Figure 1. Setup and scan orientations.

Scan orientations as shown in Figure 1. were determined at the scanning system setup process. Lower segment scan orientations look like too close to the downcomers. There are several big manholes as obstacles at $180^{\circ}$ position and nozzles at $0^{\circ}$ position. For the upper segment, the unsymmetrical scan orientations also caused by obstacles.

Lower segment scans were conducted first. The scans were started from $750 \mathrm{~mm}$ below the TL (tangent line) until $27210 \mathrm{~mm}$. The orientations (abbreviated as L1 and L2) were crossed the trays and avoided the downcomers. At the L1 line, the gamma source was positioned at $150^{\circ}$ and detector at $26^{\circ}$. While for L2, the gamma source was positioned at $210^{\circ}$ and the detector was positioned at $330^{\circ}$.

The upper scans were started from $27210 \mathrm{~mm}$ to $36710 \mathrm{~mm}$. The orientations were coded as U1 and U2. For U1, the gamma source position was at $150^{\circ}$ and detector at $10^{\circ}$. While for U2, the gamma source position was at $192^{\circ}$ and the detector position was at $313^{\circ}$.

The difference in the diameter of the upper and lower segments and the limited number of platforms to do the work in the column were challenges when conducting the set-up process. Because of working at high, hot conditions, and also the used of gamma radiation, this experiment has a very high risk. Therefore, this experiment was monitored by the safety officer and radiation protection officer. The standard personal protective equipment (PPE) for this experiment are coverall suit, safety helmet, safety glasses, safety shoes, full-body harness, earpieces, and gloves.

The scanning process was performed automatically. The scanning system has consisted of a mechanical winch with $25 \mathrm{~W}$ AC motor, microcontroller module, gamma counting system, and a personal computer with LabVIEW as the graphical user interface (GUI) as shown in Figure 2. The gamma source and detector collimators were moved up parallelly each $50 \mathrm{~mm}$ by using pulley at the top of the column and stainless-flexible slink cable to pull the collimators up. Furthermore, counting the radiation that penetrating the column. Scanning time was 3 seconds every step. The data were collected by computer using programmed LabVIEW.

During the scanning process the initial scan time and scan end time need to be noted. The information is very necesary to be confirmed to process division regarding the 
production condition at that time. Furthermore, scan line conditions must also be noted when the source collimator or detector passed through the external structures such as platform, support, reinforcement, and so on.

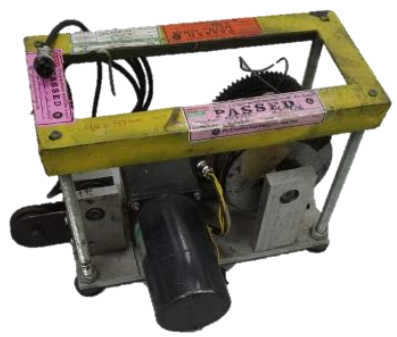

(a)

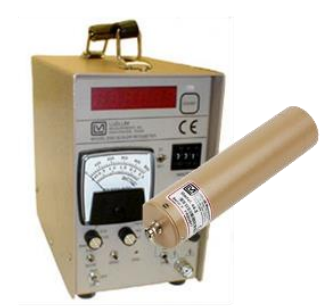

(c)

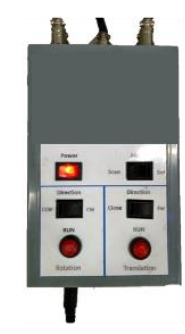

(b)

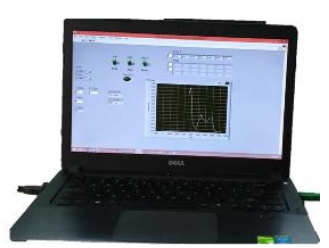

(d)
Figure 2. Automatic scanning system, (a) motorized winch, (b) controller module, (c) gamma detector and counter, (d) computer with LabVIEW as the GUI.

\section{RESULTS AND DISCUSSION}

The scan data are shown in Figure 3. Internal structures conditions of the 01-C-3401 de-ethanizer column were analyzed based on scan data. Scan profiles were compared to the CAD drawing that made based on the column mechanical drawing.

The results show the mechanical structure of tray \#1 until tray \#38 were in their position indicated by the profile of scan data, the radiation intensity was always becoming extremely lower at trays elevation than void positions. It was caused by trays material and liquid above it absorbed the gamma radiation. Overall, the gap between trays are $500 \mathrm{~mm}$ except between tray \#38 and tray \#37 (2200 $\mathrm{mm}$ ) caused by chimney, between tray \#27 and tray \#26 (1000 $\mathrm{mm})$ caused by manhole "M4" and Nozzle "N3", between tray \#18 and tray \#17 caused by manhole "M3", between tray \#9 and tray \#8 caused by bottleneck shape, and between tray \#8 and tray \#7 caused by chimney and nozzle "N1". The patterns of the scan profiles were having the same spaced distance compared to the mechanical drawing.

The liquid level above trays was in the normal condition indicated by shapes tray scan profiles, overall the trays profiles thickness was symmetric. There were no thicker profiles. Thicker tray profile means the possibility of foaming. There were weeping bellow tray \#9 and \#10 as shown in Figure 3 (c). Weeping is the presence of downward droplets in the vapor space between trays.

There were no collapsed or flooded trays in the column. Figure 3 shows there were no collapsed structures in the column. The collapsed trays or other internal structures can be observed by dissimilar patterns of the trays profile (i.e. missing tray) or observing unknown material above another tray. Flooded tray phenomenon could be known by liquid level conditions above the tray. The flooded tray can be caused by unknown material blocked the downcomer channel.

The scan profile of L1 was not so good as shown in Figure 3 (b). There are so many obstacles to that position that caused the line become inconsistent. The improper scan data might cause by gamma beam to hit the downcomer. However, the data were complemented and supported by data L2 because they hit the same tray (single pass tray).

Chimneys above tray \#38 and tray \#8 were observed exist. The chimney above tray \#38 was observed at data L1 and L2 as shown in Figure 3 (a). Chimney made liquid accumulated as high as its height. Furthermore, chimney above tray \#8 was observed at data $\mathrm{U} 1$ and U2. the thicker shape of tray \#8 indicated the chimney has existed. The unsymmetric of scan profile between U1 and $\mathrm{U} 2$ above tray \#8 caused by the U1 was hit the reinforcement of nozzle "N1".

Based on data U1 and U2 in Figure 3 (d), the demister can be stated in its position. The total thickness of the demister is $250 \mathrm{~mm}$. the existence of a demister is important to prevent liquid particles from being brought to the top product.

The liquid level during the scanning process was in normal liquid level (NLL) approaching to high liquid level (HLL). Based on Figure 3 (a), the liquid level on data L1 is $6150 \mathrm{~mm}$ above TL and L2 is $5850 \mathrm{~mm}$ above TL. While the normal liquid level (NLL) of- 


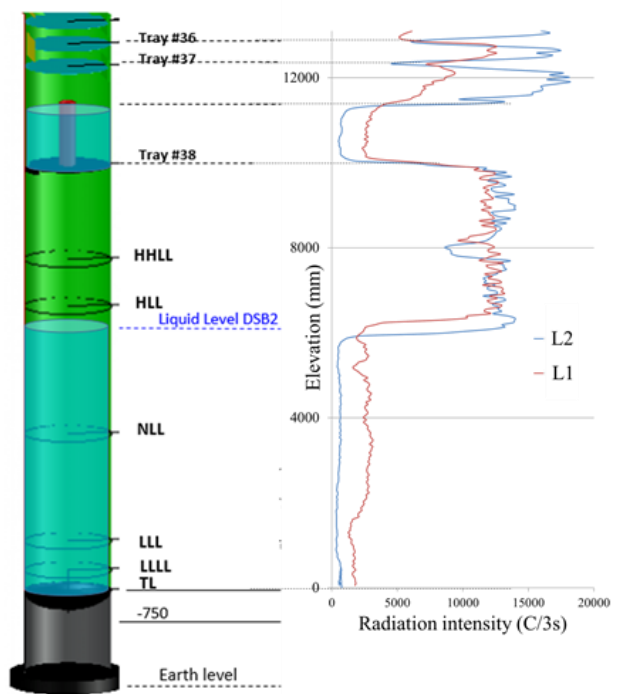

(a)

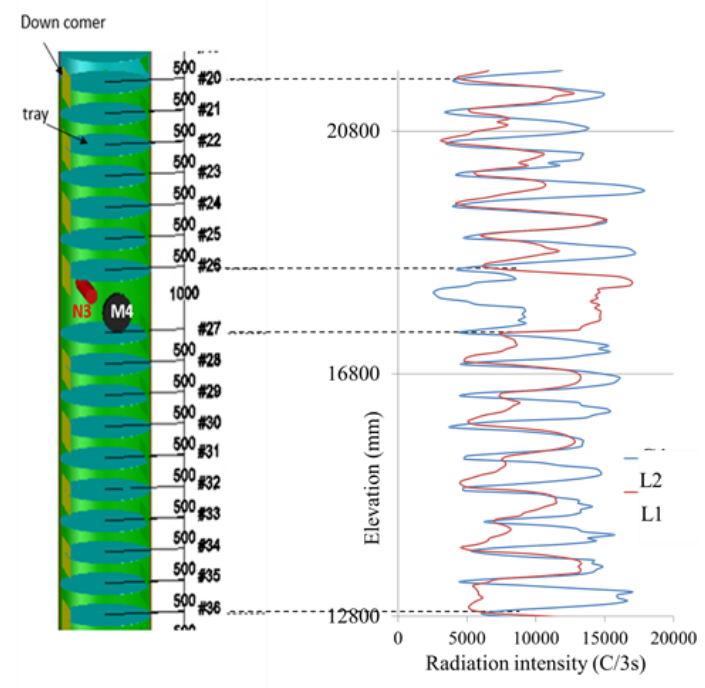

(b)

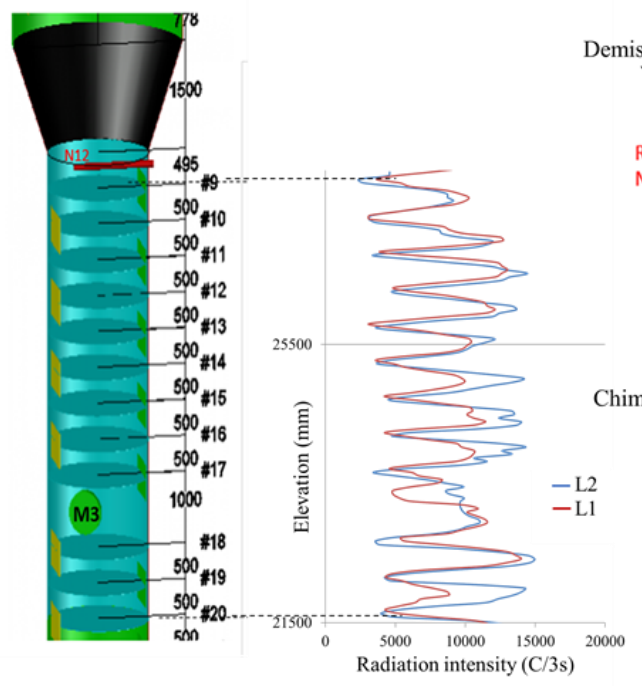

(c)

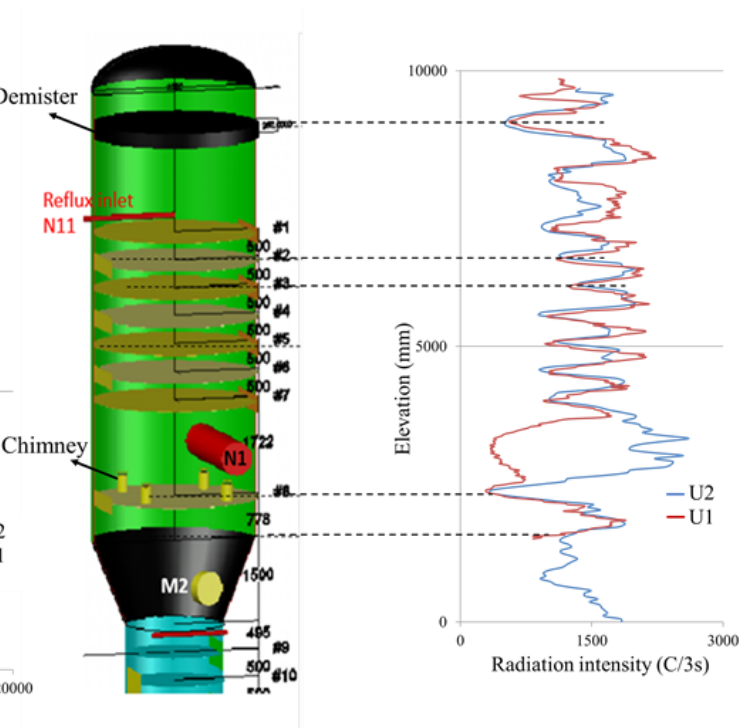

(d)

Figure 3. Scan data, (a) lower segment TL-tray \#36, (b) lower segment tray \#36-\#20, (c) lower segment tray \#20-\#9, and (d) upper segment tray \#8-demister.

the column is $3500 \mathrm{~mm}$ and a high liquid level (HLL) is $6350 \mathrm{~mm}$ above TL. The time gap between data L1 and L2 is one day.

\section{CONCLUSION}

The gamma scanning technique has been successful to provide the internal structures conditions information of the column. The mechanical structure of De-Ethanizer column was in good condition. The internal mechanical structure of tray \#1 until tray \#38 was in their position. There were weeping trays on tray \#9 and tray \#10. Liquid levels were approaching the high liquid level (HLL) during the scanning process. Overall, the 01-C-3401 de-ethanizer column was in good condition and operated under normal conditions.

\section{ACKNOWLEDGEMENTS}

The authors would like to acknowledge PT Perta-Samtan Gas and Center for Isotopes and Radiation Application-BATAN who have been continuously encouraging the realization of the application of nuclear technology in the 
field of industry. Special thanks to Mr. Melky Datuela and the team for their help and hospitality during the experiment on the field.

\section{REFERENCES}

1 T. Gao, W. Lin, and A. Gu, "Improved processes of light hydrocarbon separation from LNG with its cryogenic energy utilized," Energy Convers. Manag., vol. 52, no. 6, pp. 2401-2404, 2011.

2 A. A. Bhran and M. M. El-Gharbawy, "Modification of a deethanization plant for enhancing propane and propylene recovery and solving some operational problems," $J$. Nat. Gas Sci. Eng., vol. 31, pp. 503-514, 2016.

3 M. I. Haraguchi, W. A. P. Calvo, and H. Y. Kim, "Tomographic 2-D gamma scanning for industrial process troubleshooting," Flow Meas. Instrum., 2017.

4 J. Abdullah, "Gamma-Ray Scanning for Troubleshooting, Optimization, and Predictive Maintenance of Distilation Columns," Hydrocarb. Asia, pp. 62-65, 2005.

5 K. Laraki, R. Alami, R. C. El, A. Bensitel, and L. El Badri, "An Expert System for Improving the Gamma-Ray Scanning Technique," Nucl. Inst. Methods Phys. Res. A, vol. 578, pp. 340-344, 2007.

6 H. Shahabinejad, S. A. H. Feghhi, and M. Khorsandi, "Impact of measurement approach on the quality of gamma scanning density pro fi le in a tray type labscale column," Radiat. Meas., vol. 61, pp. 1-5, 2014.

7 H. Shahabinejad, S. A. H. Feghhi, and M. Khorsandi, "Structural inspection and troubleshooting analysis of a lab-scale distillation column using gamma scanning technique in comparison with Monte Carlo simulations," Measurement, vol. 55, pp. 375-381, 2014.

8 Wibisono and B. Azmi, "Scan on Gasoline Fractination Column to Control Production Flow Using Co-60," Semin. Nas. Sains dan Teknol. Nukl. 2017, no. November, pp. 333-337, 2017.

9 Wibisono and B. Azmi, "Identification of Scaling Thickness on 48 Inches Pipe Line using Gamma Scanning Technique," Nucl. Technol. Util., no. 021, pp. 220-224, 2017.

10 Wibisono, B. Azmi, and Z. Lubis,
"Investigation on Aluminum Pall Ring DA-302 Ethane Washer Tower used Gamma Scan and Gamma Tomography Technique," Pertem. Ilm. Iptek Bahan, no. Lll, pp. 218-225, 2016.

11 G. A. Johansen, Radioisotope Gauges for Industrial Process Measurements. John Wiley \& Sons, Ltd, 2004.

12 C. M. Pepin, P. Bérard, A. L. Perrot, C. Pépin, D. Houde, R. Lecomte, C. L. Melcher, and H. Dautet, "Properties of LYSO and recent LSO scintillators for phoswich PET detectors," IEEE Trans. Nucl. Sci., vol. 51, no. 3 II, pp. 789-795, 2004.

13 P. A. S. Vasquez, C. H. De Mesquita, G. A. C. LeRoux, and M. M. Hamada, "Methodological analysis of gamma tomography system for large random packed columns," Appl. Radiat. Isot., vol. 68, no. 4-5, pp. 658-661, 2010.

14 H. Shahabinejad and S. A. H. Feghhi, "Design , optimization and performance of source and detector colli- mators for gamma-ray scanning of a lab-scale distillation column," Appl. Radiat. Isot., vol. 99, pp. 25-34, 2015. 